\title{
The Feed and Sleep method: how to perform a cardiac MRI in the 1st year of life without the need for General Anesthesia
}

\author{
Jonathan D Windram*, Lars Grosse-Wortmann, Masoud Shariat, Mary-Louise Greer, Shi-Joon Yoo \\ From 2011 SCMR/Euro CMR Joint Scientific Sessions \\ Nice, France. 3-6 February 2011
}

\section{Introduction}

MRI in small children as a general rule necessitates the use of general anesthesia. We describe our initial results with a new technique which we name the feed and sleep method whereby an infant can undergo a Cardiac MRI without the need for general anesthesia or sedation.

\section{Methods}

The infant is starved for 4 hours prior to the scan and is then fed by his mother prior to the scan. He is then swaddled with 1 to 2 infant sheets before placed within a vacuum-bag immobilizer. As air is removed from the bag, the immobilizer becomes a rigid cradle that fits the infant's body. We prioritize the sequences to target the area of importance first according to the purposes of the study and in the order of clinical importance.

\section{Results}

Between Jan and July 2010 a total of 12 infants median age 14 days (minimum 2 days maximum 150 days ) have undergone CMR studies via this method. All were performed successfully with no distress to the infant. The average scan time was 45.5 min (minimum 24, maximum $65 \mathrm{~min}$ ). All had complex congenital heart defects (Table 1) and all planned sequences were able to be acquired ensuring the scans were of sufficient quality to allow accurate diagnosis and to plan appropriate future surgery.

\section{Table 1}

\begin{tabular}{|c|c|c|c|}
\hline $\mathrm{Pt}$ & Diagnosis & $\begin{array}{l}\text { Time of scan } \\
(\mathrm{min})\end{array}$ & $\begin{array}{l}\text { Age } \\
\text { (days) }\end{array}$ \\
\hline 1 & Right atrial isomerism, Atrioventricular Septal Defect with total anomalous pulmonary venous drainage & 37 & 2 \\
\hline 2 & Left ventricular hypoplasia & 48 & 12 \\
\hline 3 & Right atrial isomerism, Atrioventricular Septal Defect with total anomalous pulmonary venous drainage & 65 & 60 \\
\hline 4 & Total anomalous pulmonary venous drainage & 46 & 150 \\
\hline 5 & Hypoplastic Left heart syndrome, Blalock Taussig Shunt, Left pulmonary artery stenosis. & 33 & 15 \\
\hline 6 & Arteriovenous malformation & 57 & 14 \\
\hline 7 & Supracardiac total anomalous pulmonary venous drainage, left atrial isomerism with interrupted IVC & 57 & 12 \\
\hline 8 & Tetralogy of Fallot & 59 & 4 \\
\hline 9 & Aortic coarctation & 24 & 30 \\
\hline 10 & $\begin{array}{l}\text { Congenital Correction of Transposition of the Great Arteries, Atrial Septal Defect, Ventricular Septal Defect, } \\
\text { central shunt }\end{array}$ & 58 & 35 \\
\hline 11 & Double Outlet Right Ventricle, sub-pulmonary VSD, Interupted Aortic Arch (type A) & 39 & 4 \\
\hline 12 & Absent right pulmonary artery & 27 & 14 \\
\hline
\end{tabular}

The Hospital for Sick Children, Toronto, ON, Canada

\section{Biomed Central}

(c) 2011 Windram et al; licensee BioMed Central Ltd. This is an open access article distributed under the terms of the Creative Commons Attribution License (http://creativecommons.org/licenses/by/2.0), which permits unrestricted use, distribution, and reproduction in any medium, provided the original work is properly cited. 


\section{Conclusion}

Using this technique infants under the age of 6 months can complete a cardiovascular MRI, without the need for general anesthesia. We advocate the incorporation of this safe and reliable technique into routine clinical practice.

Published: 2 February 2011

doi:10.1186/1532-429X-13-S1-P224

Cite this article as: Windram et al:: The Feed and Sleep method: how to perform a cardiac MRI in the 1st year of life without the need for General Anesthesia. Journal of Cardiovascular Magnetic Resonance 2011 13(Suppl 1):P224.

Submit your next manuscript to BioMed Central and take full advantage of:

- Convenient online submission

- Thorough peer review

- No space constraints or color figure charges

- Immediate publication on acceptance

- Inclusion in PubMed, CAS, Scopus and Google Scholar

- Research which is freely available for redistribution

Submit your manuscript at www.biomedcentral.com/submit 